\title{
POKRAJINSKI VIDIKI RABE PREMOGOVNIŠKEGA UGREZNINSKEGA VELENJSKEGA JEZERA
}

\author{
Emil Šterbenk* ${ }^{*}$ Rudi Ramšak ${ }^{* *}$
}

Izvleček

UDK 556.55:504.4.054(497.4 Šaleška dolina)

Velenjsko jezero je nastalo v predalpski Šaleški dolini po drugi svetovni vojni kot posledica izkopavanja lignita. Od nastanka ga je v veliki meri onesnaževala voda za transport pepela iz šoštanjske termoelektrarne. Sredi devetdesetih so zgradili zaprt transportni sistem in onesnaževanje prekinili. Od takrat se je jezerska voda izboljšala in jezero postaja ena pomembnejših razvojnih možnosti za Šaleško dolino. Le ob upoštevanju načel trajnostnega in sonaravnega razvoja se bo jezero še naprej izboljševalo in omogočalo večplastno rabo.

Ključne besede: Izboljšanje jezerske vode, premogovništvo, elektroenergetika, trajnostno sonaravni razvoj, Šaleška dolina.

\section{RECLAIMING POLLUTED WATERS: THE CASE OF THE VELENJE LAKE}

\section{Abstract}

The Velenje Lake came into existence in the Sub-alpine Šalek Valley after the World war II due to deep coal-mining. The ash transport water from the Šštanj thermal power plant was the main source of it's pollution for three decades. The closed ash transport system has been built in the middle nineteen's to reduce pollution to the minimum. The lake has improved since than. It is becoming one of the main chances for development of the Śalek Valley. Only by consideration of the principles of the sustainable development the lake quality is further going to improve and make possible different kinds of it's use.

Key words: improvement of lake water, deep coal-mining, electricity production, sustainable development, Šalek Valley.

\footnotetext{
* Mag., prof. geog., soc., ERICo Velenje, Koroška 58, 3320 Velenje

** Dipl. biol., ERICo Velenje, Koroška 58, 3320 Velenje
} 


\section{UVOD}

Ugrezninsko območje in šaleška jezera (Škalsko, Družmirsko, Velenjsko in Turistično) sva obravnavala kot odprt, antropogeniziran pokrajinski sistem. Za raziskovanje sva uporabila funkcijsko zasnovane regionalno geografske metode $\mathrm{s}$ poudarkom na hidroloških posledicah premogovniške pokrajinske preobrazbe (Sporbeck, 1979).

$\mathrm{Na}$ dnu predalpske Šaleške doline v zadnjem stoletju nastajajo v rečni pokrajini ugrezninska jezera, ki so samo najopaznejši znak celovite premogovniške preobrazbe pokrajine (Šterbenk, Šalej, 1995). Trenutno (1998) so v treh kotanjah (ugrezninah) štiri jezera. Največje med njimi je Velenjsko, ki ga lahko v Sloveniji s površino 1,35 $\mathrm{km}^{2}$ in prostornino 25 milijonov $\mathrm{m}^{3}$ uvrstimo med večja. Kljub svoji velikosti pa so $\mathrm{v}$ Sloveniji Šaleška jezera slabo poznana (Kladnik in sodelavci, 1998). Največkrat so bila omenjana $\mathrm{v}$ zvezi z velenjskim premogovnikom in šoštanjsko termoelektrarno, in to predvsem kot okoljski problem. Manj je bilo pisanega o njih kot o možnosti za razvoj Šaleške doline in njenih naselij, predvsem Velenja in Šoštanja. Tudi prebivalci Šaleške doline jih največkrat doživljajo kot negativni pojav v pokrajini. Jezera se zaradi stalnega izkopavanja premoga pod njimi in ob njih ves čas širijo. Šele ko bo ves lignit izkopan, bodo dobila končno pokrajinsko podobo. Za raziskovalca so šaleška jezera zelo zanimiva, saj so kljub zelo majhni medsebojni oddaljenosti zaradi različnih antropogenih vplivov zelo različna. Vsekakor pa s svojimi 35 milijoni $\mathrm{m}^{3}$ vode predstavljajo akumulacijo, ki je v slovenskih okvirih ni mogoče prezreti.

\section{NASTANEK VELENJSKEGA JEZERA, NJEGOVO VEČANJE IN JEZERSKA KOTANJA}

Velenjsko jezero je trenutno največje na dolinskem dnu (Tabela 1). Leta 1960 je vsebovalo 2,6 milijona $\mathrm{m}^{3}$ vode in obsegalo 25 ha. Do leta 1998 se je po volumnu povečalo skoraj desetkrat ( 25 milijonov $\mathrm{m}^{3}$ ), po površini pa več kot petkrat (135 ha). Dolgo je $1430 \mathrm{~m}$ in široko $1210 \mathrm{~m}$. S svojo globino $54 \mathrm{~m}$ je globlje od Bohinjskega $(45 \mathrm{~m})$. Jezero je skoraj pravilne, pravokotne oblike, breg je malo razčlenjen, zato je majhen tudi njegov obseg $(4850 \mathrm{~m})$. Izkopavanje premoga je pod vzhodnim in južnim jezerskim bregom že večinoma zaključeno, zelo intenzivno je le še pod zahodnim bregom. Tam ugreznino sproti zasipavajo z elektrofiltrskim pepelom iz šoštanjske elektrarne. Večjih sprememb $\mathrm{v}$ obliki, površini in prostornini Velenjskega jezera $\mathrm{v}$ prihodnje ni pričakovati.

Tabela 1: Spremembe površine in prostornine Velenjskega jezera (Jamomerstvo Premogovnika Velenje, 1998) 


\begin{tabular}{|l|c|c|c|c|}
\hline Leto & $\begin{array}{c}\text { Površina } \\
\text { (ha) }\end{array}$ & $\begin{array}{c}\text { Verižni } \\
\text { indeks }\end{array}$ & $\begin{array}{c}\text { Prostornina } \\
\left(\text { mio m }^{3}\right)\end{array}$ & $\begin{array}{c}\text { Verižni } \\
\text { indeks }\end{array}$ \\
\hline 1960 & 25 & 100 & 2,6 & 100 \\
\hline 1970 & 22 & 88 & 1,1 & 42 \\
\hline 1980 & 93 & 372 & 13,5 & 519 \\
\hline 1990 & 123 & 492 & 20,8 & 800 \\
\hline 1998 & 135 & 540 & 25,0 & 962 \\
\hline
\end{tabular}

\section{ODLAGANJE PEPELA IZ ŠOŠTANJSKE TERMOELEKTRARNE V JEZERO IN NA NJEGOV BREG}

Do leta 1983 je bilo Velenjsko jezero odlagališče za pepel iz šoštanjske termoelektrarne. Suspenzijo pepela in vode - pepelno brozgo - so črpali vanj po ceveh. Pri takšnem transportu se iz pepela izlužijo različni hidroksidi, ki alkalnost vode izredno stopnjujejo. Zaradi tega je bil pH jezera tako visok (12), da v njem ni bilo živih organizmov. Da bi zmanjšali negativne vplive na jezero, so leta 1983 spremenili tehnologijo odlaganja. Pričeli so graditi odlagališče pepela kot nasip na zahodnem bregu Velenjskega jezera (Tamše 1996). Pepel se je usedel v usedalnikih, onesnažena transportna voda pa je še vedno tekla $v$ jezero. Od tam je odtekala po jezernici v Pako, njen $\mathrm{pH}$ je občasno presegel 11. Visoka alkalnost jezera je bila edini omejitveni (vodno degradacijski) dejavnik za razvoj živih organizmov v jezeru, vse druge okoliščine pa so bile ugodne.

Po pričetku gradnje odlagališča pepela kot nasipa se je pokazalo, da je glavni, tako rekoč edini vzrok za onesnaženost Velenjskega jezera pepelna transportna voda. Da bi preprečili onesnaževanje jezera in Pake, so leta 1994 zgradili zaprti sistem odpepeljevanja. Onesnaženo vodo zbirajo pod odlagališčem in jo vračajo $\mathrm{V}$ elektrarno, kjer jo ponovno uporabijo za transport pepela. Onesnažena voda sedaj kroži skoraj brez negativnih vplivov na jezero in druge vode v Šaleški dolini. 
Slika 1: Alkalnost Velenjskega jezera (pH) poleti 1991 in v obdobju od leta 1994 do 1997 (povzeto po: Ramšak, 1998; Beričnik-Vrbovšek in drugi 1995, 1996)

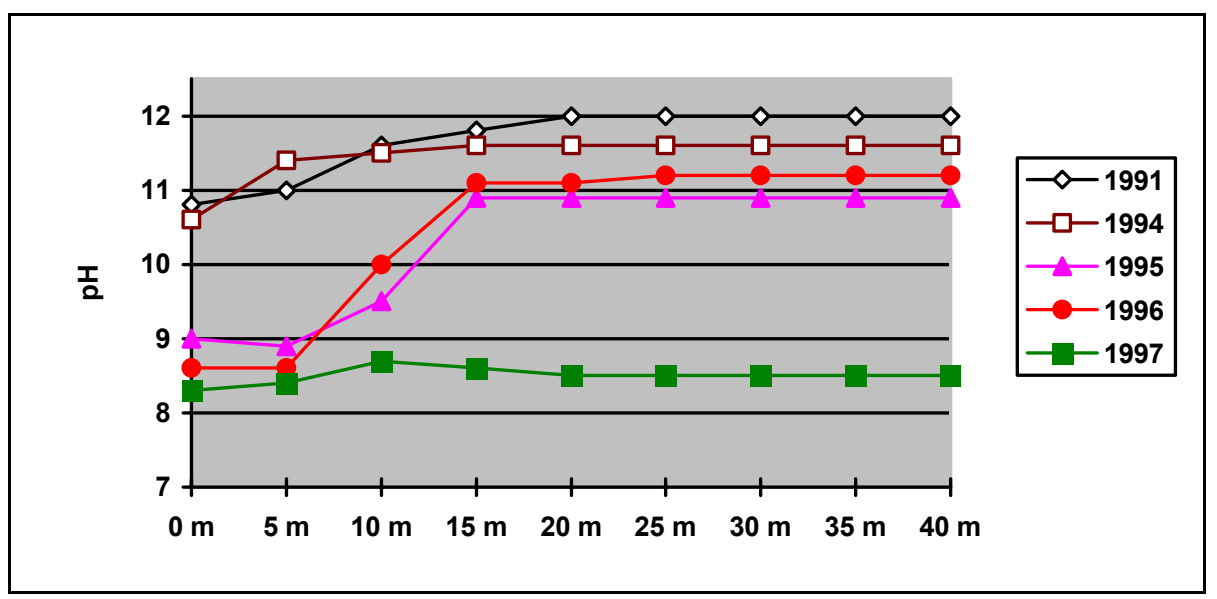

Kakovost jezerske vode se je izboljšala in vanj se po daljšem obdobju spet vračajo različni vodni organizmi. Poleti 1995 se je pH epilimnija (vrhnje plasti jezera) zmanjšal pod 9, medtem ko je še poleti 1991 znašal skoraj 11. Naslednje poletje je kakovost epilimnija s pH 8,5 že ustrezala za kopanje, leta 1997 pa alkalnost vode v nobeni globini ni presegla $\mathrm{pH} 8,7$ (Slika 1).

\section{POJEZERJE VELENJSKEGA JEZERA}

Padavinsko zaledje Velenjskega jezera meri $20,4 \mathrm{~km}^{2}$. Več kot polovico predstavlja više ležeče Škalsko pojezerje s Škalskim jezerom vred. Pojezerje je razmeroma nizko. Sega do absolutne višine $900 \mathrm{~m}$, vendar leži skoraj devet desetin površja nižje od $700 \mathrm{~m}$ absolutne višine oziroma 300 m relativne. Višji deli ne dobivajo bistveno več padavin kot jezero. Letni dotok vode $v$ jezero znaša dobrih 11 milijonov $\mathrm{m}^{3}$. Da se voda $\mathrm{v}$ njem teoretično zamenja, je potrebno več kot dve leti (Šterbenk, 1998).

Več kot $60 \%$ pojezerskega sveta prerašča gozd, kar je za Velenjsko jezero ugodno, saj zmanjšuje negativne vplive prebivalstva, premogovništva (predvsem povečane erozije in denudacije prsti) in kmetijstva. V pojezerju Velenjskega jezera živi okrog 2000 prebivalcev (ocena) oziroma približno 100 prebivalcev $/ \mathrm{km}^{2}$. Pozitivno za jezero je, da je na njegovem bregu v večji meri zgrajena kanalizacija in da odpadne vode prečrpavajo na šoštanjsko čistilno napravo. V zaledju jezera je največje naselje Škale, ki šteje 800 prebivalcev, pa še to ni povsem strnjeno. Kmetijstvo v pojezerju je 
intenzivno, vendar je ugoden blažilni vpliv gozda, tako da jezerski pritoki zaradi kmetijstva niso močneje onesnaženi. Kljub temu pa je jezerski sistem občutljiv in imajo lahko že manjši antropogeni posegi znatne posledice.

\section{ORGANIZMI V VELENJSKEM JEZERU}

Ko je jezero onesnaževala pepelna transportna voda, so bile redke modrozelene alge edini organizmi v njem. Šele po prekinitvi onesnaževanja (po letu 1994) lahko govorimo o ponovnem življenju v Velenjskem jezeru.

V epilimnijski plasti jezera so bili po letu 1994 pogosto navzoči planktonski organizmi in tudi ribe, $\mathrm{v}$ začetku sicer bolj ob pritokih v jezero, kasneje pa tudi po vsem obrežnem delu. Hipolimnij je bil še v letu 1996 obremenjen s hidroksidi. Kljub temu so ribe $\mathrm{v}$ zgornji plasti jezera živele vse leto. V poskusnem ribolovu, novembra 1996, so bile ujete vrste: krap, klen, rdečeperka, rdečeoka, zelenika, ostriž. V jezeru pa živijo tudi postrv, ščuka, ploščič, som in druge vrste.

Od rastlinskih organizmov so se po prenehanju elektrarniškega onesnaževanja najpogosteje pojavljale kremenaste alge (Diatomea), zelene (Chlorophyta) in modrozelene alge (Cyanophyta). Pogoste so bile tudi alge iz skupine Dinophyta in Chrysophyta. Od živalskih organizmov (zooplankton) so bili najpogostejši kotačniki (Rotatoria), sledijo kopepodni rakci (Copepoda) in vodne bolhe (Phyllopoda).

V letu 1997 so se življenjske razmere še dodatno izboljšale, saj se je alkalnost znižala tudi v spodnjih jezerskih plasteh. Poleg živalskega in rastlinskega planktona smo v letu 1997 opazovali razbohotenje obrežnih makrofitov, katerih sestoji so poleg trstičja sestavljali prave podvodne gozdove. Najbolj pogosti so bili sestoji: klasasti rmanec Myriophyllum spicatum L, kodravi dristavec - Potamogeton crispus L, nitastolistni dristavec - Potamogeton filiformis Pers, rumeni blatnik - Nuphar luteum, velika podvodnica- Naja marina (je redka v Sloveniji), mala podvodnica - Naja minor. Ponekod se pojavlja tudi vrsta alg Chara sp., ki je značilna prebivalka bolj čistih voda (Ramšak, 1998).

Jezero je s svojim cvetenjem v zadnjih dveh poletjih (1997 in 1998) opozorilo, da je občutljiv ekosistem. Vendar vzrok ni zgolj v antropogenem onesnaževanju, pač pa tudi $\mathrm{v}$ neuravnoteženosti jezera, saj se življenjske razmere $\mathrm{v}$ njem še vedno spreminjajo. 


\section{VELENJSKO JEZERO - RAZVOJNA MOŽNOST ZA ŠALEŠKO DOLINO}

"Gozdarska in rudarska mesta niso stabilne skupnosti. To so le začasne skupnosti prebivalcev, ki so jih zgradili zato, da bi jih nekoč zapustili." (Young, Sachs, 1995.) Ta trditev za Velenje ne velja $\mathrm{v}$ celoti, saj ni nastalo zgolj zaradi premogovništva. Vendar je $\mathrm{v}$ obdobju po drugi svetovni vojni premogovnik predstavljal največje zaposlitveno središče v Šaleški dolini, njegov delež se je do leta 1998 zmanjšal na petino šaleških delovnih mest in petino skupnega prihodka gospodarskih družb. Izguba 4000 delovnih mest bi pomenila padec standarda in gospodarsko ter družbeno nestabilnost za prebivalce Šaleške doline.

Slika 2: Delež skupnega prihodka gospodarskih družb v upravni enoti Velenje leta 1996 (vir: Šuster, 1997).

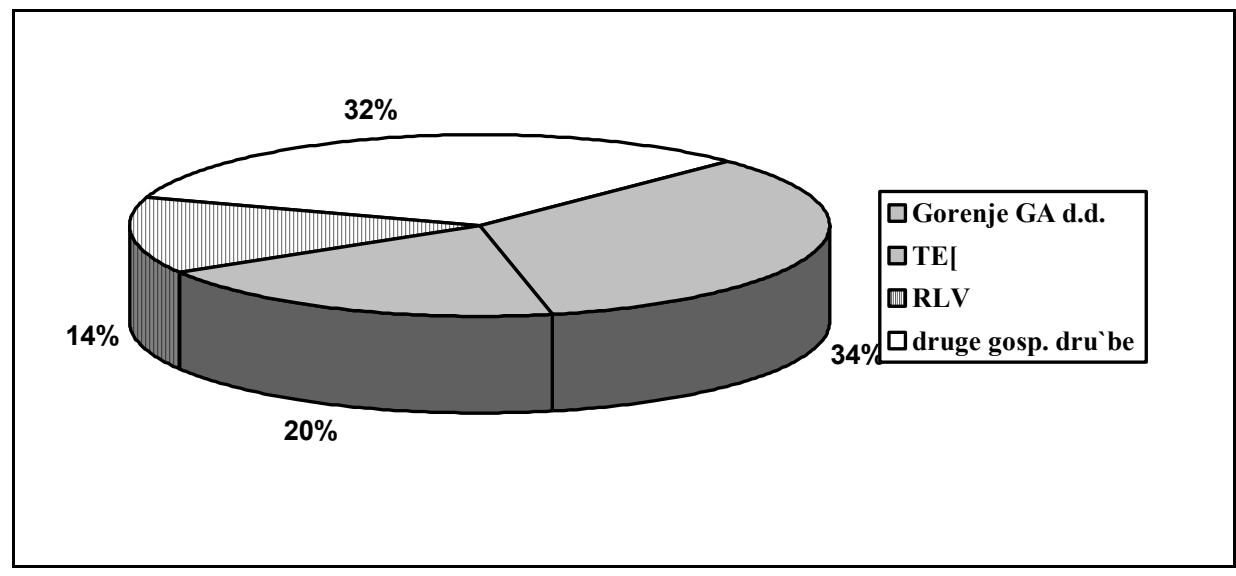

Razmerje ni tako ugodno, kot ga prikazuje graf 2 , saj so mnoga manjša podjetja $\mathrm{v}$ veliki meri odvisna od premogovnika. Obstoj premogovnika je omejen z zalogami lignita, ki jih je še za petdeset let. Ta čas je potrebno kar najbolje izkoristiti za gospodarsko prestrukturiranje Šaleške doline. Jezera postajajo pokrajinski element, ki se vedno pogosteje pojavlja $\mathrm{v}$ različnih razvojnih programih.

Ob Velenjskem in Škalskem jezeru je že nastalo rekreacijsko središče (Tamše, 1994), ki je leta 1998 zaposlovalo več kot 60 ljudi (gostinstvo, Turistično rekreacijski center, stadion, konjereja). Območje je bilo v celoti poškodovano zaradi premogovniškega ugrezanja, sedaj pa je urejeno (rekultivirano) in v rekreacijski oziroma kmetijski rabi. Velenjska posebnost je vrtičkarsko naselje "Kunta-Kinte", ki predstavlja eno izmed oblik rekultivacije ugreznin. Jezerski breg s površino 5 ha so razdelili na približno $200 \mathrm{~m}^{2}$ velike parcele in tako dobili več kot 200 vrtov, ki so jih dali v najem. 
Najemniki so lahko postavili lope za orodje, ki so počasi postale bivalni prostori. Sedaj ne moremo več govoriti o vrtičkarskem, ampak o turističnem naselju. Zaradi izboljšanja jezerske vode postaja to naselje vedno bolj privlačno in, predvsem poleti, ostajajo lastniki tam vedno dlje časa.

$\mathrm{Na}$ jezerskem bregu so urejene sprehajalne poti, ki privabljajo vedno več sprehajalcev, tekačev in drugih rekreativcev. Izboljšana jezerska voda je postala primerna za kopanje. Natančnih analiz o številu rekreativcev ni, dejstvo pa je, da se v jezeru in ob njem rekreira vedno več ljudi. Poleti 1998 se je ob nedeljah v jezeru kopalo že tudi do 200 ljudi na dan.

Zaradi gnezdišč številnih vrst ptic so severovzhodni jezerski breg sklenili spremeniti v krajinski park. Ta del brega ni rekultiviran in se zarašča po naravni poti. Nastal je deloma močviren ekotop, ki je z obiljem vrst bogastvo za Velenje, saj lahko najdemo "neoskrunjeno" naravo le $2 \mathrm{~km}$ od mestnega središča.

Rekultivirane površine na severni strani jezera so namenili kmetijstvu, saj z ugrezanjem tal v Šaleški dolini izginjajo najrodovitnejše ravninske površine, ki so primerne za kmetijstvo.

$\mathrm{V}$ nasprotju $\mathrm{z}$ drugimi deli jezerskega brega pa se njegov zahodni del še vedno ugreza. Tam je odlagališče oziroma pepelni nasip, ki pa je zadnje čase že manj moteč, saj ga sproti ozelenjujejo, tako da ni več tako očitna rana v pokrajini. Vsekakor pa do zaključka izkopavanja pod njim ne moremo pričakovati spremenjene rabe.

\section{PREDLOGI SONARAVNEGA GOSPODARJENJA Z VELENJSKIM JEZEROM IN NJEGOVIM BREGOM}

Vse vrste rekreacijske rabe, naselja in kmetijstvo pomenijo dodatno obremenjevanje jezera. Toda osnovni pogoj za razvoj rekreacije ob jezeru in $\mathrm{v}$ njem je njegova čistost. Zato mora biti sonaravna in trajnostna raba jezera osnovno izhodišče pri načrtovanju rekreacijskega območja. Obremenjevanje jezera in njegovih bregov ne sme presegati samočistilnih sposobnosti občutljivega jezerskega ekotopa.

Krajinski park je zelo pomemben za ravnotežje jezera, saj od tam ne prihaja do negativnih vplivov. Po tej plati je pravzaprav že tudi varstveni ukrep za jezero. Tudi odlagališče (nasip) pepela na jezero ne vpliva več negativno in glede na način gradnje nasipa tudi v prihodnje ni pričakovati večjih in trajnejših negativnih vplivov, posebej zato, ker ob njegovem ugrezanju ni mogoča kakšna druga raba.

Največji naselji v jezerskem zaledju, Škale in Hrastovec, imata v večji meri zgrajeno kanalizacijo oziroma lahko govorimo kar o krožni kanalizaciji jezera. V najbližji prihodnosti je treba na ta sistem priključiti vse stanovanjske zgradbe tega območja.

Kmetijstvo v Šaleški dolini je intenzivno. To velja tudi za zaledje Velenjskega jezera. Osnovni ukrep, ki je brez večjih problemov izvedljiv, je neposredni varstveni pas, kjer bi omejili oziroma odpravili gnojenje (npr. $10 \mathrm{~m}$ od jezera). Vsaj v neposredni 
bližini jezera pa bi morali namesto gnojevke uporabljati hlevski gnoj. Vsekakor pa bi veljalo tudi omejiti gnojenje tik ob jezerskih pritokih in zmanjšati njegovo intenzivnost v celotnem pojezerju.

Največji negativni vpliv predstavlja Škalsko jezero, ki je meromiktično (globlje od 6 $\mathrm{m}$ je plast $\mathrm{z}$ raztopljenim vodikovim sulfidom $-\mathrm{H}_{2} \mathrm{~S}$ ). Zaradi svoje organske obremenjenosti in velike količine hranil vpliva negativno na nižje ležeče Velenjsko jezero. "Zdravljenje" Škalskega jezera ni namenjeno samo njemu samemu, ampak pomeni tudi izboljšanje razmer za Velenjsko jezero. Med obema jezeroma leži ribogojnica, od koder prihajajo hranila v Velenjsko jezero. Zato je potrebno skrbno odmerjanje ribje hrane in zmanjšanje intenzivnosti.

Vrtičkarsko naselje "Kunta-Kinte" je prav tako izvor hranil za jezero, saj ob vodovodu ni kanalizacije, ki je nujno potrebna. Zaradi izboljšanja jezera pa lahko pričakujemo še večji obisk tega območja.

$Z$ večanjem števila kopalcev se veča tudi negativni vpliv na jezero. V kratkem se bo pojavil problem parkirišč in kopališke infrastrukture. Tudi drugi vodni športi (čolnarjenje, deskanje, jadranje) zahtevajo infrastrukturo in prostor na jezeru.

\section{SKLEP}

Mlado Velenjsko jezero, ki je nastalo v predalpski Šaleški dolini kot posledica izkopavanja lignita $\mathrm{v}$ velenjskem premogovniku, je ves čas močno izpostavljeno antropogenim vplivom. Jezero še ni dokončno morfološko izoblikovano, saj pod delom njegovega dna in brega še vedno kopljejo lignit. Do srede devetdesetih let je visoka alkalnost, ki je bila posledica transporta in odlaganja pepela na njegovem vzhodnem delu, onemogočala življenje organizmov $v$ njem. Po prenehanju onesnaževanja je za jezero značilno hitro naseljevanje z živimi organizmi, predvsem $s$ planktonom in $\mathrm{z}$ algami. Za vzpostavitev ravnotežja med jezerskimi organizmi je potrebno veliko časa. Jezero je zadnji dve leti poleti tudi prvič cvetelo, cvetenje je bilo zaznavno, ne pa množično (Šterbenk, Rošer-Drev, 1997). S tem nas opozarja, da so zanj nevarni še tako majhni antropogeni vnosi.

Velenjsko jezero postaja pomemben dejavnik razvoja Šaleške doline. Na njegovem bregu nastaja rekreacijsko središče, ki si utira pot v slovensko rekreacijsko-turistično ponudbo. Trenutno je pomemben predvsem za krajevno prebivalstvo. Toda jezero bo privlačno le ob ustrezni čistosti, zato je nujno potrebno nadaljevati $\mathrm{z}$ varstvenimi ukrepi. Predvsem je potrebno vse posege vanj in njegovo pojezerje pretehtati z vidika okoljskih vplivov. Vse dejavnosti $\mathrm{v}$ jezeru in ob njem morajo upoštevati nosilnost okolja in njegove samočistilne sposobnosti. Le tako je mogoče doseči sonaraven in trajnostni razvoj ter $\mathrm{s}$ tem jezero in njegov breg ohraniti tudi za prihajajoče generacije. 


\section{LITERATURA IN VIRI}

1. Joung E.J, Sachs A. 1995: Trajnostno gospodarjenje z materiali. Zemlja 1995, poročilo inštituta Worldwatch o prizadevanjih za trajnostno družbo - prevod. Medium, D. O. O. Radovljica..

2. Kladnik in sodelavci, 1998: Slovenija pokrajine in ljudje. Mladinska knjiga. Ljubljana.

3. Ramšak R, 1998: Raziskave in spremljanje kakovosti jezer v Šaleški dolini, poročilo za leto 1997. ERICo Velenje.

4. Sporbeck O., 1979: Bergbaubedingte Veranderungen des physischen Nutzungspotentials (dargestel am Beispiel des linksrheinischen Braunkohlenrevirs). Paderborn.

5. Šterbenk E., Radinja D., 1997: Hidrološke spremembe v subalpski Šaleški dolini zaradi premogovništva in elektroenergetike. Sanacija termoenergetskih objektov, zbornik 1. mednarodnega simpozija. Velenje.

6. Šterbenk E., Ramšak R., 1995: Velenjsko jezero znova živi. Naš čas 27/95. Velenje.

7. Šterbenk E., Rošer-Drev A., 1997: Poročilo o cvetenju Velenjskega jezera avgusta 1997. ERICo Velenje, Inštitut za ekološke raziskave. Velenje. DP 19697.

8. Šterbenk E., Šalej M., 1995: Antropogena jezera v Šaleški dolini. Geografski obzornik 4/1995. Ljubljana.

9. Šuster V., 1997: Informacija o poslovnem izidu in premoženjsko - finančnem položaju gospodarskih družb v letu 1996, občina Velenje. Agencija republike Slovenije za plačilni promet, podružnica Velenje. Velenje.

10. Tamše M., 1994.: Perspektive razvoja Šaleške doline. Šaleški razgledi, Zbornik 1994/1995. Velenje.

11. Tamše M., 1996: Uporaba pepela in industrijskih odpadkov pri sanaciji zemljišč v Šaleški dolini. Zbornik posvetovanja Uporaba pepela in industrijskih odpadkov $\mathrm{v}$ tehnoloških procesih in pri sanaciji okolja. Cetera d.o.o. Ljubljana. 